\title{
Notes on mites of the family Myobiidae (Acari: Prostigmata) parasitising rodents (Mammalia: Rodentia) in Iran
}

\author{
Andre Bochkov ${ }^{1}$, Masoud Arbobi $^{2}$ and Vladimir Malikov ${ }^{1}$ \\ ${ }^{1}$ Zoological Institute, Russian Academy of Sciences, Universitetskaya Emb. 1, 199034, Saint-Petersburg, Russia; \\ ${ }^{2}$ Department of Agricultural Zoology, Plant Pests and Diseases Research Institute, Ministry of Agriculture, Evin, Tabnak Av., \\ Tehran, Iran
}

Key words: Acari, Myobiidae, Radfordia, Myobia, rodents, Iran

\begin{abstract}
Six mite species of the family Myobiidae, Radfordia (Austromyobia) persica sp. n., Radfordia (Austromyobia) merioni Bochkov, Dubinina et Chirov, 1990, Radfordia (Radfordia) acomys Fain et Lukoschus, 1977, Radfordia (Radfordia) affinis (Poppe, 1896), Radfordia (Graphiurobia) dyromys Fain et Lukoschus, 1973, and Myobia (Myobia) murismusculi (Schrank, 1781) were found in Iran on the rodents Gerbillus cheesmani Thomas, Meriones libycus Lichtenstein, Acomys cahirinus (Desmarest), Mus musculus L., Dryomys nitedula (Pallas), and Mus musculus, respectively. R. (A.) persica is described as a new species from the female, male and tritonymph. The other five myobiid species are new to Iran.
\end{abstract}

The mites of the family Myobiidae Mégnin, 1778 (Acari: Prostigmata) are permanent monoxenic or oligoxenic ectoparasites of small marsupial and placental mammals (Mammalia) (Dusbábek 1969, Fain 1994). The mites of the nominal subfamily Myobiinae are associated exclusively with rodents (Mammalia: Rodentia) (Bochkov 1997a). Despite of the fact that more than 100 species belonging to six genera have been included to this subfamily, the myobiid fauna is unevenly known and in some regions has not been investigated at all. One of these regions is Iran, the myobiine mites of rodents from Iran being those especially unexplored. Only one myobiid species, Radfordia (Microtimyobia) cricetulus Fain, 1973, has so far been known in this country from the grey hamster Cricetulus migratorius (Pallas) (Cricetidae) (Fain 1973). The aim of the present paper is to partly fill in the gap in our knowledge of this mite group. The description of Radfordia (Austromyobia) persica sp. n., and of the tritonymph of Radfordia (Radfordia) acomys Fain et Lukoschus, 1977 as well as a list of the myobiid species found in Iran by us are given bellow.

\section{MATERIALS AND METHODS}

A total of 79 ethanol-preserved rodent specimens (14 species belonging to four rodent families) collected in Iran in 1997-1998 were examined for mites. Six myobiid species belonging to two genera were found on Gerbillus cheesmani Thomas, Meriones libycus Lichtenstein (both Gerbillidae), Acomys cahirinus (Desmarest), Mus musculus L., (both Muridae) and Dryomys nitedula (Pallas) (Gliridae).

Description of setal nomenclature follows Fain's (1973) system except for minor modifications in the nomenclature of the genital setae (Bochkov 1997a). Three anterior pairs of genital setae $(g 1-g 3)$ are named herein as paragenitals ( $p g)$. All measurements are given in micrometres with ranges in parentheses.

\section{RESULTS}

Family: $\quad$ Myobiidae Mégnin, 1778

Genus: $\quad$ Radfordia Ewing, 1938

Subgenus: Austromyobia Lawrence, 1954

Radfordia (Austromyobia) persica Bochkov, sp. n.

Figs. 1, 2A-C

Description: The species bears all characters of the subgenus Austromyobia (species group forcipifer): setae of gnathosoma $\mathrm{ra}$ hair-like. Setal formula of coxa, trochanter, femur, genu, tibia and tarsus of legs II-IV in adults (excluding solenidions): II 3-3-5-7-6-7, III 1-3-36-6-6, IV 1-3-3-5-6-6; coxal setae hair-like; dorsal seta of trochanters III-IV lash-like, longer than legs; setae $v i$ short, hair-like; setae 13 of female lanceolate; genital shield of male round, with 8 paires of setae (including setae $d 1$ ): one pair of setae finger-like, 7 pairs of setae narrow lanceolate or hair-like; dorsal surface of tritonymph with 13 pairs of setae, anal setae absent.

Female (holotype, Fig. 1A-B). Body length (gnathosoma included), 348 (337-382 in 4 paratypes), width between legs II and III 270 (236-275). Setae vi 11 (1118) long; ve $81(81-87) \times$ approx. 11 (length $\times$ width); sci $101(101-103) \times$ approx. 9; sce $78(78-81) \times$ approx. $11 ; d 167$ (65-68) and $d 263$ (63-67) long, width approx. $4 ; d 3, d 4$ and $d 522$ (22-27), 45 (40-47) and 12 (11-14) long respectively, all hair-like; $l 167$ (67-72) $\times$ approx. 4; 1274 (69-74) $\times$ approx. 4; 1350 (50-69) long; 1442 (33-42) long, slightly thicker; ic1, ic2, ic3 and ic4 25 (24-31), 69 (67-78), 78 (69-85) and 11 (9-11) long 

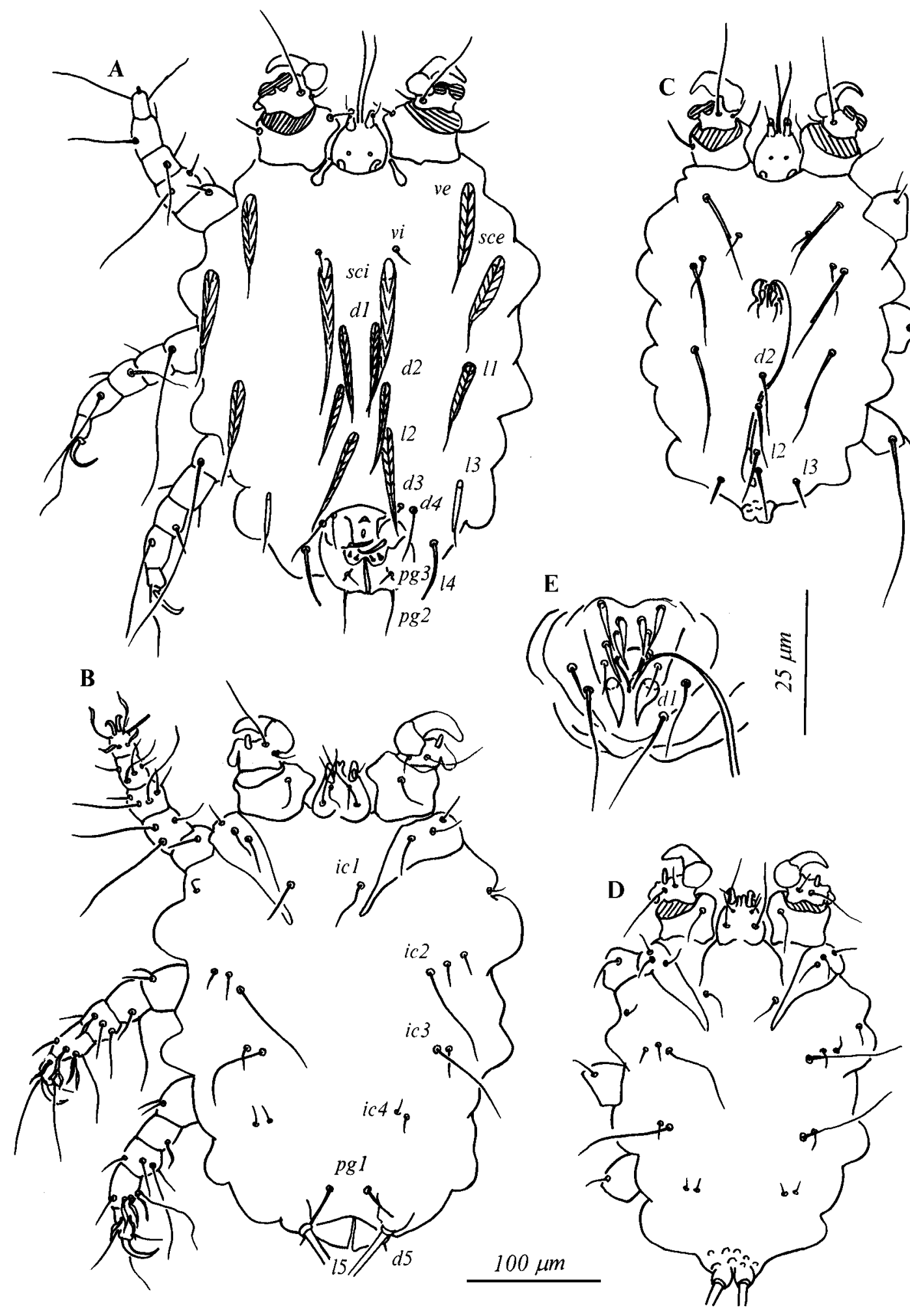

Fig. 1. Radfordia (Austromyobia) persica sp. n. A - holotype female, dorsal view; $\mathbf{B}$ - same, ventral view; $\mathbf{C}-$ male, dorsal view; D - same, ventral view; $\mathbf{E}$ - genital shield of male.

respectively; pg1 and pg2 23 (25-33) and 40 (38-47) $\quad d 2$ subequal to distance between bases of setae $d 2-l 2$. long respectively. Distance between bases of setae $d 1-\quad$ Genu III bears 6 setae. 
Male (Fig. 1C-E). Body length (gnathosoma included) 258-292 (in 3 paratypes), width between legs II and III 191-202. Length of setae: vi 11-12; ve 56-60, sce 67-69, $l 1$ 58-72, all narrow lanceolate; sci 33-36, $d 2$ 27-36, l2 29-36, l3 22-23, ic1 15-22, ic2 51-67, ic3 5672, ic4 8-10, all hair-like. Aedeagus 157-168 long; genital shield as in Fig. 1E. Chaetotaxy of legs as in female.

Tritonymph (Fig. 2A-C). In this subgenus there are no distinctive differences between female and male tritonymphs (Bochkov 1997c). Body length (gnathosoma included) 281-393 (in 5 paratypes), width 258281. Setae $v i$, ve, sci, sce, $d l$ and $l 1$ are 31-42, 49-56, $72-81,90-101,76-81$ and 103-112 long respectively, all 5-6 width; $d 2$ 47-49 × 4; d3 18-22, d4 69-78, l2 24-33, 13 18-22, 14 40-58, all narrow lanceolate, 2-3 width; $d 5$ very short, 5-6; icl 15-22, ic2 38-45, ic3, ic4 4-8, all hair-like. Tarsus of leg IV as in Fig. 2C; with 6 relatively short setae; claw absent.

T y p e s p e c i e s : Gerbillus cheesmani Thomas, 1919 (Gerbillidae), the Cheesman's gerbil.

T y p e 1 o c a 1 i t y : Iran, Yazd Province, $30 \mathrm{~km}$ north-west of Hojat-Abad.

D a t e of c o 11 e c t i o n :27. 04. 1998; F. Golenichshev and V. Malikov coll.

T y p e $\mathrm{m}$ a t e r i a 1 : Holotype female, paratype 4 females, 3 males, 10 tritonymphs, 6 deutonymphs and 1 protonymph.

De pos ition of materia 1 : Holotype female (coll. No. T-My-31), 3 paratype males (No. P-My-31, 2, 4-5), 8 tritonymphs (No. P-My-31, 1, 3, 6-11), 6 deutonymphs (No. P-My-31, 13-18) and 1 protonymph (No. P-My-31, 12) in the Zoological Institute of the Russian Academy of Sciences, Saint-Petersburg; 1 paratype female and 1 tritonymph (coll. No. 1970) in the Institute of Parasitology, Academy of Sciences of the Czech Republic, České Budějovice; 1 paratype female and 1 tritonymph in Institute Royal des Sciences Naturelles of Belgique, Bruxelles.

E t y m o log y: The species is named after the geographical region in which it was collected.

Differential diagnosis. The adults of $R$. (A.) persica bear 6 setae on genu III. This is the characteristic feature of the species group forcipifer (6 species) (Bochkov 1997c), but only in three species within this group the setae ic4 are short as in $R$. (A.) persica.

The new species is most closely related to Radfordia (A.) gerbillus Fain et Lukoschus, 1977 from the lesser Egyptian gerbil Gerbillus gerbillus (Olivier), the type host, from Egypt, and from the Baluchistan gerbil Gerbillus nanus Blanford from Tunis (Fain and Lukoschus 1977). The male of R.(A.) gerbillus is unknown; the female has been described briefly but not figured. However, the tritonymph has been described and figured in detail.

The tritonymph of the new species differs from that of the latter species by length of setae $d 4, l 4$, and $i c 3$, which are 69-78, 40-58 and 4-8 respectively; the length ratio of setae $d 1-d 2$ is about $1.5: 1$. According to the original description, length of setae $d 4$ and $l 4$ in $R$. (A.) gerbillus tritonymph is $10-25$ and of ic 345 ; the length ratio of setae $d 1-d 2$ is about $1.1: 1$ (Fain and Lukoschus 1977).

Furthermore, the new species is close to Radfordia (A.) aegyptica Radford, 1951 from North African gerbils of the genera Gerbillus and Dipodillus (Radford 1951, Bochkov 1997d). The male of Radfordia aegyptica is almost indistinguishable from, but the female is well differentiated by the following characters from the new species. In the female of $R$. (A.) persica setae $d 4, d 5$ and $l 4$ are 40-47, 11-14 and 33-42 long respectively; setae $d 4$ are about 1-1.2 times longer than setae 14 ; setae 14 are slightly thicker; in the deutonymph setae $i c 3$ are short as $i c 4$. In female $R$. (A.) aegyptica setae $d 4, d 5$ and $l 4$ are 47-51, 23-25 and 23-26 long respectively; setae $d 4$ are about twice as long as setae 14; setae 14 are thin, hair-like; in the deutonymph setae $i c 3$ are as long as $i c 2$.

The female of $R$. (A.) persica is well distinguished from the female of $R$. (A.) forcipifer Lawrence, 1954 from South African gerbils of the genus Tatera (Lawrence 1951, Fain 1978) by the length ratio of distances between bases of setae $d 1-d 2$ and $d 2-l 2(1: 1$ in the new species, 3:1 in $R$. (A.) forcipifer).

\section{Radfordia (Austromyobia) merioni Bochkov, Dubinina et Chirov, 1990}

Material examined. One tritonymph from the Libyan gerbil Meriones libycus Lichtenstein (Gerbillidae); Markazi Province, near Arak, 7. 11. 1996, H. Bogdanova and V. Malikov coll.

Distribution. The type host of this species is the tamarisk gerbil Meriones tamariscinus (Pallas) from Kirghizia (Bochkov et al. 1990). This species is a parasite of the gerbils of the genus Meriones. It has been recorded from the midday gerbil Meriones meridianus (Pallas) from Uzbekistan (Bochkov 1997c) and $M$. tamariscinus from Kirghizia (Bochkov et al. 1990). Meriones libycus is a new host record.

\section{Subgenus: Radfordia}

\section{Radfordia (Radfordia) acomys Fain et Lukoschus, 1977 Fig. 2D-G}

Material examined. Ten females, 7 males, 7 tritonymphs, 6 deutonymphs and 2 protonymphs from the spiny mouse Acomys cahirinus (Desmarest) (Muridae); Hormozgan Province, near Hodji-Abad, 6. 02. 1998, V. Malikov coll.; 19 females, 9 males, 8 tritonymphs, 1 protonymph and 1 larva from the same host, Balauchistan, near Choboghar, 17. 12. 1996, V. Malikov coll.

Remarks. This species was described from Acomys cahirinus from Zoo Hamburg (Germany) (Fain and Lukoschus 1977). Later, it was relegated to the separate 


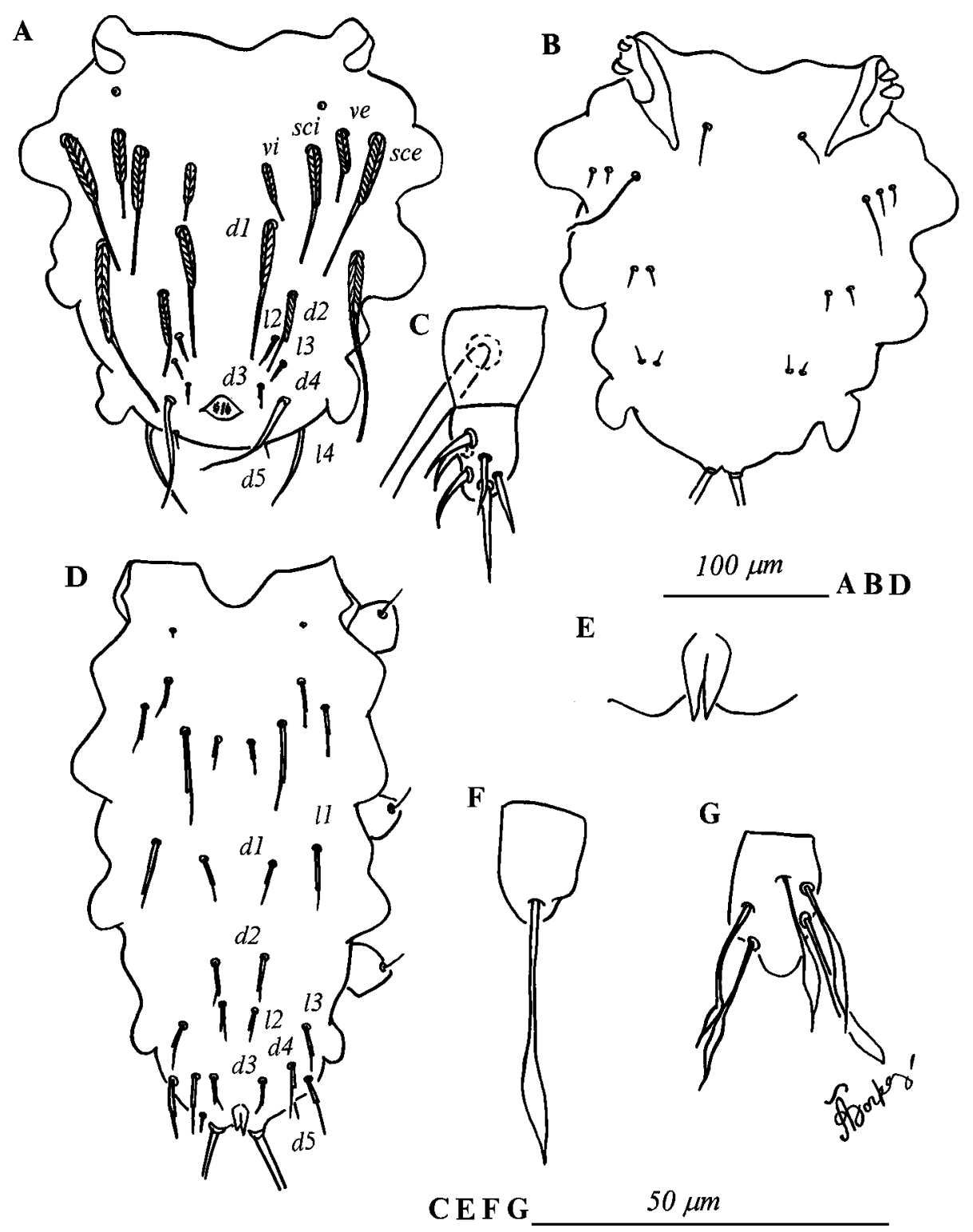

Fig 2. Details of tritonymphs of Radfordia species. A-C: Radfordia (Austromyobia) persica sp. n. A - idiosoma, dorsal view; B - same, ventral view; C - tarsus IV, dorsal view. D-G: Radfordia (s. str.) acomys Fain et Lukoschus. D - idiosoma, dorsal view; $\mathbf{E}$ - anus; $\mathbf{F}$ - tarsus IV, dorsal view; $\mathbf{G}$ - same, ventral view.

species group acomys (Bochkov and Fain 1997). The immature stages of $R$. (s. str.) acomys have not been described. However, the morphology of tritonymphs is important for differentiating of the species groups and subgroups within the subgenus Radfordia. Herein we give the description of the tritonymph for the first time.

Tritonymph (Fig. 2D-F). In this subgenus there are no distinctive differences between female and male tritonymphs (Bochkov and Fain 1997). Body length (gnathosoma included) 430-465 (in 5 specimens), width 227-240. All setae of dorsal surface narrow lanceolate, 3-5 width (except hair-like setae $d 5$ ). Length of setae: $v i$ 20-24, ve 22-25, sci 56-60, sce 30-38, d1 29-34, d2 36-
$44, d 3$ 24-27, d5 9-15, l1 51-65, l2 43-47, l3 31-36, l4 36-38; anal setae absent. All setae of ventral surface hair-like, very short, 3-6 long and only setae ic2 18-32 long. Tarsus of leg IV as in Fig. 2F-G, with 5 relatively short setae ventrally and one long seta dorsally; claw absent.

\section{Radfordia (Radfordia) affinis (Poppe, 1896)}

Material examined. One female from the house mouse Mus musculus L. (Muridae); Tehran city, 12. 10. 1996, V. Malikov coll.; 15 females, 8 males, 10 tritonymphs from the same host, Tehran, 12. 10. 1997, V. Malikov coll. 
Distribution. This species was described from Mus musculus in Germany (Poppe 1896) and is cosmopolitan (Fain and Lukoschus 1977). It was also recorded from the field mouse Apodemus sylvaticus (L.) (Muridae) from Belgium and Ukraine (Fain and Lukoschus 1977, Bochkov 1997b), from the yellownecked mouse Apodemus flavicollis (Melchior) from Crimea (Bochkov 1997b), from the little Indian field mouse Mus booduga (Gray) from India, and from Mus castaneus Waterhouse from Philippine islands (Fain and Lukoschus 1977).

Subgenus: Graphiurobia Fain, 1972

\section{Radfordia (Graphiurobia) dyromys Fain et Lukoschus, 1973}

Material examined. One female from the forest dormouse Dryomys nitedula (Pallas) (Gliridae); Kerman Province, ShahDad Tonnel, Kuh-Benan Mountains, 30. 04. 1998, V. Malikov, F. Golenichshev and J. Gourchenko coll.; one tritonymph, deutonymph and protonymph ex the same host with the same data.

Distribution. This host-species specific parasite was described from Dryomys nitedula (Fain and Lukoschus 1973). It is distributed in Poland, Turkey (Fain and Lukoschus 1973) and Russia (near Anapa) (Bochkov 1994).
Genus: Myobia Heyden, 1826

\section{Myobia (Myobia) murismusculi (Schrank, 1781)}

Material examined. Sixteen females, 1 male and 3 tritonymphs from Mus musculus; Kerman Province, Sardueh, Bahr-e-Aseman Mountains, 08. 09. 1996, V. Malikov and M. Arbobi coll.; one female from the same host; Tehran, 10. 10. 1996, V. Malikov coll.

Distribution. This species was described from Mus musculus in Germany (Schrank, 1781). It is a parasite of Mus musculus and of mice of the genus Apodemus (subgenus Sylvaemus): Apodemus flavicollis and $A$. sylvaticus (Fain and Lukoschus 1977, Bochkov 1997b). It is distributed all over the world together with the house mice (Fain and Lukoschus 1977).

Acknowledgements. We are grateful to Dr. F. Golenichshev (Zoological Institute of the Russian Academy of Sciences., Russia), Dr. H. Bogdanova, Dr. M. Saulich (Plant Protection Institute, Russia) and Mrs. J. Gourchenko for providing us with the specimens of rodents collected during their field work in Iran and for identification of the host species. We are also highly obliged to Iranian colleagues Mr. A. Sh. Vaziri, Mr. F. Nazari and Mrs. N. Zemannishad (Plant Pests and Diseases Research Institute, Iran) for their great assistance in the survey.

\section{REFERENCES}

BOCHKOV A.V. 1994: Mites of the subgenus Graphiurobia (Myobiidae, Radfordia) of the fauna of Russia and surrounding states. Parazitologiya 28: 421-428. (In Russian.)

BOCHKOV A.V. 1997a: New classification of myobiid mites (Acari, Acariformes). Entomol. Obozr. 76: 938-951. (In Russian.)

BOCHKOV A.V. 1997b: Myobiid mites (Acariformes: Myobiidae) parasitizing the rodent family Muridae (Rodentia) in Russia and neighbouring countries. Parazitologiya 31: 201-209. (In Russian.)

BOCHKOV A.V. 1997c: Two new subgenera of myobiid mites of the genus Radfordia (Acariformes: Myobiidae). Entomol. Obozr. 76: 684-704. (In Russian.)

BOCHKOV A.V. 1997d: Description of the female of the mite Radfordia (Austromyobia) aegyptica (Acariformes: Myobiidae). Parazitologiya 31: 458-461. (In Russian.)

BOCHKOV A.V., DUBININA E.V., CHIROV P.A. 1990: The first record of mites of the subgenus Austromyobia (Acariformes, Myobiidae) from fauna of the USSR. Izv. Akad. Nauk Kirg. SSR Ser. Khimiko-tekhn. Nauk 1: 5566. (In Russian.)

BOCHKOV A.V., FAIN A. 1997: On the systematics of mites of the subgenus Radfordia s.str. (Acari: Myobiidae: Radfordia). Acarina 5: 19-28.

DUSBÁBEK F. 1969: To the phylogeny of genera of the family Myobiidae (Acarina). Acarologia 11: 537-574.
FAIN A. 1973: Notes sur la nomenclature des poils idiosomaux chez les Myobiidae avec description de taxa nouveaux (Acarina: Trombidiformes). Acarologia 15: 279-309.

FAIN A. 1978: Les Myobiidae d'Afrique au sud du Sahara et de Madagascar (Acarina-Prostigmata). Ann. Mus. R. Afr. Cent., Sér. Zool. 224: 1-186.

FAIN A. 1994: Adaptation, specificity and host-parasite coevolution in mites (Acari). Int. J. Parasitol. 24: 12731283.

FAIN A., LUKOSCHUS F.S. 1973: Note sur un nouveau Myobiidae parasite Dyromys nitedula (Acarina: Trombidiformes). Bull. Ann. Soc. R. Entomol Belg.. 109: 320-322.

FAIN A., LUKOSCHUS F.S. 1977: Nouvelles observations sur les Myobiidae parasites de rongeurs (Acarina: Prostigmates). Acta Zool. Pathol. Antverp. 69: 11-28.

LAWRENCE R.F. 1951: New fur-mite from South African mammals. Ann. Natal Mus. 12: 91-133.

POPPE S.A. 1896: Beitrag zur Kenntnis der Gattung Myobia v. Heyden. Zool. Anz. 19: 327-333.

RADFORD C. 1951: A revision of the fur-mites Myobiidae (Acarina) (suite). Bull. Mus. Natl. Hist. Nat. (Paris) 23: 269-276.

SCHRANK F.P. 1781: Pediculus muris musculi. Enum. Insect. Austria Indig. 1058: 513. 